\title{
Screening for the Heterotrophic Cultivation of Chlorella sorokiniana Using an Indirect Impedance Microbiological Technique
}

\author{
Balázs József Nagy¹, Réka Czinkóczky¹, Áron Németh* \\ 1 Department of Applied Biotechnology and Food Science, Faculty of Chemical Technology and Biotechnology, \\ Budapest University of Technology and Economics, H-1111 Budapest, Budafoki út 6-8, Hungary \\ ${ }^{*}$ Corresponding author, e-mail: naron@f-labor.mkt.bme.hu
}

Received: 16 July 2018, Accepted: 08 October 2018, Published online: 09 November 2018

\begin{abstract}
Heterotrophic culturing of microalgae is of great interest as it has the potential to produce feedstock for added-value bioproducts. The general expectation is to develop a method that can help screen for different media compositions and batch fermentation settings more easily and faster. In the current study, an indirect impedance microbiological technique was used to test the effects of various carbon and nitrogen sources on the growth of Chlorella sorokiniana. It was found that this technique has great potential to screen for heterotrophic cultivation conditions of microalgae as the metabolic rate of microorganisms can be determined by measuring the amount of $\mathrm{CO}_{2}$ produced. The BacTrac $4100^{\circledR}$ was proven to be a suitable instrument to compare several different small-scale culturing settings. Considering the relative changes in impedance observed, the initial cell cumber exhibits an inverse linear correlation with the detection time. Chlorella sorokiniana exhibited an enhanced degree of growth on yeast extract and tryptone, and preferred glucose over acetate or glycerol. An optimum rate of growth at a glucose concentration of $20 \mathrm{gL}^{-1}$ was also determined. Our novel approach in the field of heterotrophic cultivation of microalgae envisages great prospects for the method in terms of the design of experiments in the field of media optimization.
\end{abstract}

Keywords

indirect impedance microbiology, high-throughput, heterotrophic, Chlorella sorokiniana, media optimization

\section{Introduction}

Chlorella species are the most studied strains of microalgae due to their high rates of growth and lipid productivity. Many studies have reported that the biomass composition of Chlorella strains is feasible as a resource for biorefining [1], in addition to the synthesis of biofuels [2], biopolymers [3], nutraceuticals [4] and forage [5]. Microalgae technology has also been extensively tested at wastewater treatment facilities [6, 7].

In this respect, the thermotolerance of Chlorella sorokiniana also attracts special attention with regard to the development of culturing technology, especially in terms of lipid production and biomass productivity. Generally, the stress factors, such as salinity [8], nutrient depletion [9] as well as osmolarity [10], affect the lipid content of Chlorella, however, the biomass productivity depends mainly on the culturing technique. Chlorella sorokiniana grows well under autotrophic conditions, but higher concentrations of biomass have been reached under mixotrophic and heterotrophic conditions using glucose or acetate as a carbon source [11, 12]. Moreover, mixotrophic culturing can be 2.4-fold and 5.4-fold more effective in terms of biomass production than heterotrophic culturing and photoautotrophic culturing, respectively [13].

Cultivating Chlorella using heterotrophic culturing techniques has gained more attention in the field of algal research. Over the past five years, 148 new publication records have been listed in the Thomson Reuters' Web of Science Core Collection portal according to a search for the keywords "Chlorella" and "heterotrophic".

The growing interest in heterotrophic culturing of microalgae raises the need for a small-scale, high-throughput, online method suitable for selecting the right components of media and circumstances for a specific strain of microalgae. Impedance microbiological techniques may provide a solution to this general fermentation task. 
Impedance microbiology is mostly implemented in the food industry to analyze food standards from the perspective of specific pathogens. Furthermore, it is used to determine the lethal dose of antibiotics on specific microorganisms, although there are new experiments where biological impedance fingerprints are used to distinguish between microorganisms based on their specific metabolic capabilities, or to measure cell lysis generated by bacteriophages [14-17].

Several instruments that measure impedance are available, one of them is the BacTrac $4100 \circledR$ by SY-LAB. It is designed to detect the decrease in the impedance of a medium in real time which indirectly refers to the increase in conductivity caused by charged compounds formed during the metabolism of the microorganisms. The appearance of the measurement signal results in a positive curve, even though the decrease in conductivity is indicative of a relative change in impedance when compared to the initial value. Two measuring techniques exist. In the case of the direct measurement method, electrodes are immersed directly in the media, providing the possibility to measure changes in impedance in the media as well as on the surface of the electrode. It is advised that the latter should be used for media of high salinity (i.e. conductivity), in which measurements are difficult. In the case of indirect measurements, outer vials and electrodes are immersed in $0.2 \% \mathrm{KOH}$ to track the increase in impedance as a result of carbonate ions formed from the production of $\mathrm{CO}_{2}$ by the culture in the inner vial. For quantitative measurements a threshold was defined, e.g. $10 \%$, and a detection time determined until the relative change in impedance had reached the threshold. Over the past three decades both techniques have been comprehensively studied $[16,18]$.

The indirect method has been tested on the microalgae Haematococcus pluvialis to detect heterotrophic growth on different carbon and nitrogen sources. Two culturing media were tested thoroughly, the Whitley Impedance Broth (WIB) and the HKU algal selective media (Don Whitley Scientific, Shipley, England). Gong et al. observed significant differences when the experimental conditions were changed by analyzing the profile of the negative conductivity gradient. They concluded that Haematococcus pluvialis prefers acetate as a carbon source rather than glucose at a concentration of $1 \mathrm{~g} / \mathrm{L}$. It has also been determined that any culture media is suitable for the indirect method which facilitates the heterotrophic growth of the specific microalgae [19].
All these findings prompted us to presume that the impedance microbiological technique can provide a fast, small-scale, online method for media optimization of heterotrophic microalgae cultivation using batch fermentation. Based on these findings, the same settings, with some adjustments, were used. In this research, the indirect method of impedance microbiology was used to identify preferred carbon and nitrogen substrates for $C$. sorokiniana.

\section{Materials and Methods \\ 2.1 Microalgae cultivation}

The microalgae strain Chlorella sorokiniana (SAG 21132) was obtained from the Experimental Phycology and Culture Collection of Algae (EPSAG) at Goettingen University in Germany. It was maintained at $4{ }^{\circ} \mathrm{C}$ on a complex agar consisting of $5 \mathrm{~g} / \mathrm{L}$ yeast extract, $10 \mathrm{~g} / \mathrm{L}$ tryptone, $5 \mathrm{~g} / \mathrm{L}$ peptone, $20 \mathrm{~g} / \mathrm{L}$ malt extract, $5 \mathrm{~g} / \mathrm{L}$ glucose, $5 \mathrm{~g} / \mathrm{L}$ sodium chloride and $20 \mathrm{~g} / \mathrm{L}$ bacteriological agar. The compounds were obtained from SigmaAldrich. The precultures were prepared heterotrophically in $250 \mathrm{ml}$ Erlenmeyer flasks containing $100 \mathrm{ml}$ of Whitley Impedance Broth $(11.5 \mathrm{~g} / \mathrm{L}$ tryptone, $10 \mathrm{~g} / \mathrm{L}$ lactalbumin hydrolysate, $5 \mathrm{~g} / \mathrm{L}$ meat peptone, $3 \mathrm{~g} / \mathrm{L}$ yeast extract, 0.5 $\mathrm{g} / \mathrm{L} \mathrm{MgSO}_{4} \cdot 7 \mathrm{H}_{2} \mathrm{O}$ and $0.1 \mathrm{~g} / \mathrm{L} \mathrm{CaCl}_{2}$ ) in the absence of lactalbumin hydrolysate and supplemented with $10 \mathrm{~g} / \mathrm{L}$ glucose at $25^{\circ} \mathrm{C}$ whilst being stirred at $250 \mathrm{rpm}$ for 3 days. Each experiment was inoculated with a fresh culture.

\subsection{Impedance measurements}

A BacTrac $4100^{\circledR}$ instrument developed by SY-LAB (Neupurkersdorf, Austria) was used. The system is equipped with two software programs. BacMonitor ${ }^{\circledR}$ allows the parameters of the experiment to be set and the measuring points to be registered. As measurements are very sensitive, several noise factors may occur, especially as a result of changes to the ambient temperature. BacEval ${ }^{\circledR}$ provides the possibility to smooth out (by using the DropStop function) and evaluate the curves. BacEval ${ }^{\circledR}$ can export raw measured curves in the form of PDFs, thus, for further evaluation and calculations data points were readout and transferred to an Excel spreadsheet by Digitizeit (Bormisoft, Germany).

Impedance measurements were performed at $28{ }^{\circ} \mathrm{C}$ and the arrangements of the indirect measuring cells were almost the same as implemented by Gong and Chen [19] with the difference that the SY-LAB accessories were used. In our case the outer tubes were filled with $1 \mathrm{ml}$ of $0.09 \mathrm{M}$ $\mathrm{KOH}$ solution supplemented with $1 \%$ agar. The inner tubes 
contained $5 \mathrm{ml}$ of inoculated culture media. The stock solutions for the experimental setups were prepared in disposable flasks beforehand, inoculated with $20 \mu \mathrm{l}(0.1 \%$ volume ratio) of concentrated (4000 g x 5 min.) microalgae suspension, then divided into three BacTrac $4100^{\circledR}$ inner tubes as non-independent replicates. The initial cell count was $10^{5}$ cells $\mathrm{ml}^{-1}$ in all cases. A negative, non-inoculated sample was also incubated for each experiment. All stock solutions were set to $\mathrm{pH}$ 6-7 and sterilized at $121{ }^{\circ} \mathrm{C}$ for 30 minutes.

The changes in impedance were recorded every 10 minutes for $60-120$ hours by the BacTrac $4100^{\circledR}$ system. The threshold was set at $-50 \%$ in $\mathrm{M}$ value (i.e. impedance measurement of the media in $\mathrm{KOH}$ solution). The comparison of the resultant curves (M\% vs. time) was illustrated by SigmaPlot (v12.0). The averaged curves of the three non-independent replicates together with a fitted regression line of 5 th order to all data points per experimental setting are presented in all the figures. Indirect measurements resulted in negative slopes of sigmoid growth curves, but for the sake of easier evaluation the absolute values were taken into consideration.

Except for the lag time, the same parameters were analyzed according to the BacTrac $4100^{\circledR}$ curves as implemented by Bancalari et al. [15], but for the determination of maximum specific growth rates a more typical approach (Eq. (1)) was used to determine this parameter [13, 20].

\subsection{Experimental settings}

The BacTrac $4100^{\circledR}$ batch cultivations were tested using 5 independent experimental settings. Different nitrogen sources were compared in media manufactured by HKU by replacing the potassium nitrate with yeast extract, urea or tryptone and applying them in a nitrogen-equivalent content of $4.4 \mathrm{~g}$ nitrogen per liter supplemented with $25 \mathrm{~g} / \mathrm{L}$ glucose.

The carbon sources were screened in HKU and WIB media supplemented with sodium acetate at a carbon concentration of $1 \mathrm{~g} \mathrm{C} / \mathrm{L}, 1 \mathrm{~g} \mathrm{C} / \mathrm{L}$ glycerol and 1-2 g C/L glucose. The HKU media consisted of $0.5 \mathrm{~g} / \mathrm{L} \mathrm{KNO}_{3}$, $0.195 \mathrm{~g} / \mathrm{L} \mathrm{K}_{2} \mathrm{HPO} 4,0.062 \mathrm{~g} / \mathrm{L} \mathrm{MgSO}_{4} \cdot 7 \mathrm{H}_{2} \mathrm{O}, 0.184 \mathrm{~g} / \mathrm{L}$ $\mathrm{CaCl}_{2} \cdot 6 \mathrm{H}_{2} \mathrm{O}$ and $1 \mathrm{ml} / \mathrm{L}$ of a trace-metal solution which consisted of $2.7 \mathrm{mg} / \mathrm{L}$ vitamin $\mathrm{B} 12,18 \mathrm{mg} / \mathrm{L}$ EDTA, $24.4 \mathrm{mg} / \mathrm{L} \mathrm{FeCl}_{3} \cdot 6 \mathrm{H}_{2} \mathrm{O}, 72 \mathrm{mg} / \mathrm{L} \mathrm{ZnSO}_{4}, 12 \mathrm{mg} / \mathrm{L} \mathrm{H}_{3} \mathrm{BO}_{3}$, $4 \mathrm{mg} / \mathrm{L} \mathrm{CoCl} \cdot 6 \mathrm{H} 2 \mathrm{O}, 62 \mathrm{mg} / \mathrm{L} \mathrm{CuSO}_{4} \cdot 5 \mathrm{H}_{2} \mathrm{O}, 84 \mathrm{mg} / \mathrm{L}$ $\mathrm{MnSO}_{4} \cdot \mathrm{H}_{2} \mathrm{O}$ and $38 \mathrm{mg} / \mathrm{L}\left(\mathrm{NH}_{4}\right)_{6} \mathrm{Mo}_{7} \mathrm{O}_{24} \cdot 4 \mathrm{H}_{2} \mathrm{O}$.

In order to determine the glucose optimum in the case of biomass production, the changes in impedance were investigated at 8, 16, 24, 32 and $40 \mathrm{~g} \mathrm{C} / \mathrm{L}$ glucose concentrations in the WIB media at $28 \mathrm{C}^{\circ}$.

\subsection{Cell number determination and microscopy}

At the end of the impedance measurement, the optical density of the samples was measured by a spectrophotometer (Pharmacia LKB Ultrospec) at a wavelength of $750 \mathrm{~nm}$, so by estimating the final biomass concentration, each experimental setup was comparable. The possibility of the presence of infectious agents was checked by investigating the phase contrast using a Jenaval microscope. The cell numbers of some samples were also determined using a Bürker chamber under the microscope, then the final cell number was calculated using a calibration curve that plotted optical density against cell number:

$$
\begin{gathered}
\text { cell number }\left(\mathrm{db} \mathrm{ml}^{-1}\right)=2 E+07 * O D_{750}-7 E+06 \\
R^{2}=0.98
\end{gathered}
$$

\subsection{Calculation of the maximum specific growth rate} $\left(\mu_{\max }\right)$

The registered curves of change in relative impedance were used to evaluate the growth kinetics of Chlorella sorokiniana. The maximum specific growth rate was specified during the exponential phase and calculated according to Eq. (1):

$\mu_{\max }=\frac{\ln N 1-\ln N 0}{\mathrm{t} 1-\mathrm{t} 0}$

\subsection{Statistical analysis}

Statistical analyses were performed using the one-way analysis of variance (one-way ANOVA) and Tukey's multiple comparison test, a $p$ value of less than 0.05 was considered significant. The measurements were conducted in triplicates, the mean and standard deviation (SD) were calculated using GraphPad Prism 7.

\section{Results and Discussion}

The metabolism of microalgae is really complex since they can grow via 3 different ways: autotrophic, heterotrophic and mixotrophic. While the biomass activity was to be measured via $\mathrm{CO}_{2}$ formation, it needs to be taken into consideration that $\mathrm{CO}_{2}$ is released under heterotrophic conditions (via central carbon metabolism, i.e. the tricarboxylic acid (TCA) cycle, glyoxylate cycle and pentose phosphate pathway (PPP) [21]), and is consumed under autotrophic conditions but under mixotrophic conditions its role is not fully understood. The applied BacTrac $4100^{\circledR}$ equipment is capable of ensuring complete darkness inside the reactor tubes, therefore, is excellent 
for the study of heterotrophic growth via $\mathrm{CO}_{2}$ formation. It is also expected that in more suitable media more cells are grown more rapidly, resulting in an increase in the rate of $\mathrm{CO}_{2}$ formation. Thus, the profiles of $\mathrm{CO}_{2}$ formation were used to study the growth of the alga. First the effect of the initial cell number was investigated, then optimal nitrogen and carbon sources were selected, and finally two temperatures were compared on optimized media.

\subsection{Effect of different initial cell numbers on indirect impedance changes}

The major outcome of impedimetric tests is the detection time, which is generally inversely correlated with the initial cell number. Our measured curves are presented in
Fig. 1. In Fig. 1A, the same colors indicate the non-independent parallel runs, which were combined and evaluated by fitting a regression line (Fig. 1B). It is clearly visible that an increase in the initial cell number results in a decrease in the detection time.

On the basis of the curves in Fig. 1C, by applying a threshold at $\mathrm{M} \%=50$, a strong linear inverse correlation is observed between the initial cell number and detection time.

This suggests that the consumption rate of the carbon source was higher in the case of a higher initial cell number. The relative impedance was also changed in the non-inoculated tube by $14 \%$. The collection of maximum specific growth rates $\left(\mu_{\max }\right)$ is also presented in Fig. 1B. The results exhibit a similar trend as discussed previously.

A
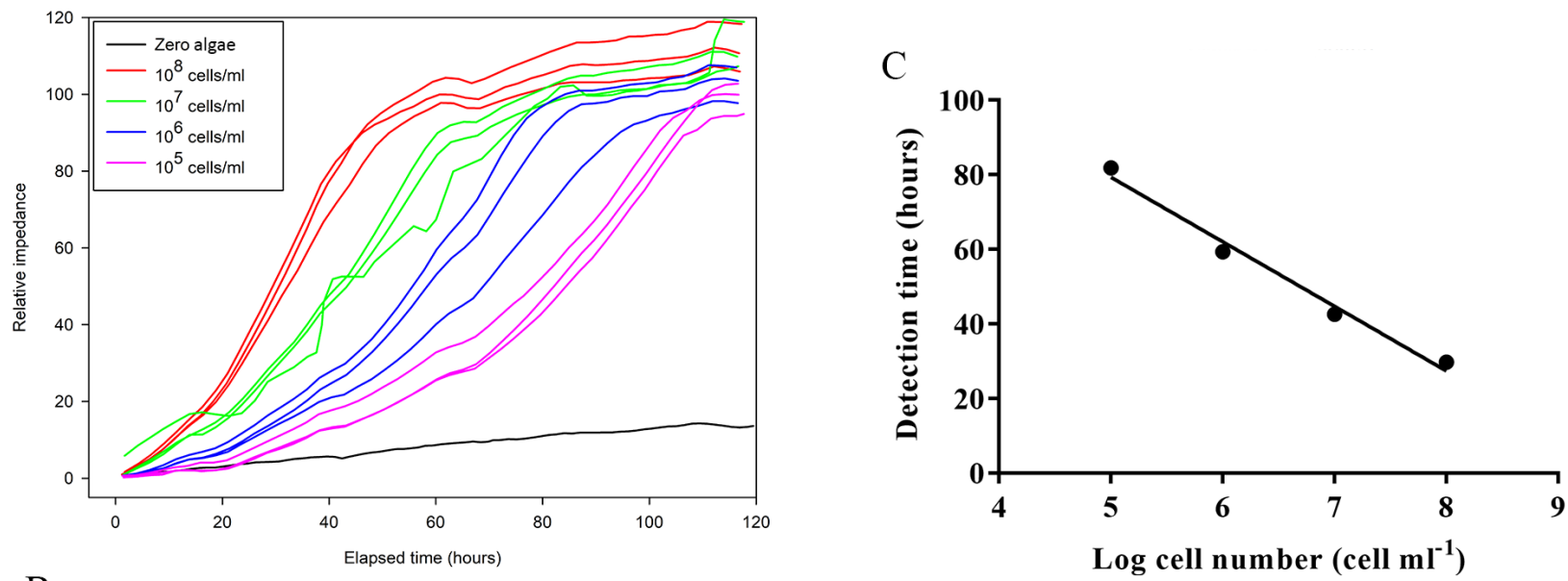

B

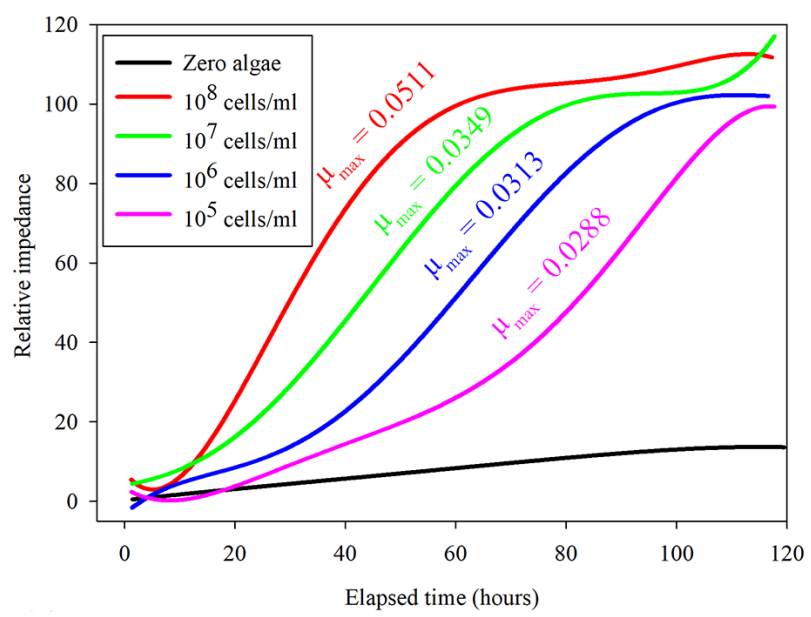

$\mathrm{D}$

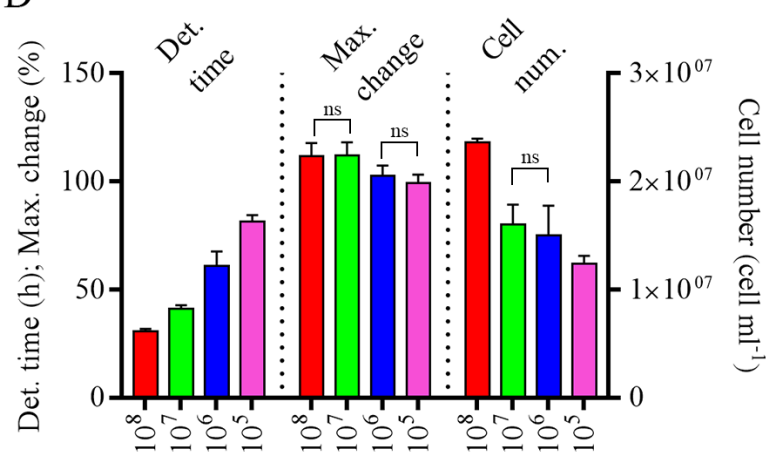

Fig. 1 Relative impedance changes of the heterotrophic culture Chlorella sorokiniana with different initial cell numbers at $28^{\circ} \mathrm{C}$ in $\mathrm{WIB}$ media supplemented by $16 \mathrm{C} \mathrm{g} / \mathrm{L}$ glucose. A) the raw data of three replications per experimental setup. B) a 5th order regression line fitted on the whole combined dataset per experimental setup. C) the observed correlations between detection time and initial cell number. D) Parameters of the measured curves (detection time, maximum change in relative impedance, final cell number). Data were expressed as the means and standard deviations of 


\subsection{Effect of nitrogen sources on microalgal impedance changes}

Comparative investigations have focused on the effect of different nitrogen sources on the biomass growth and lipid production of Chlorella. Most algal strains require a suitable type of nitrogen source, therefore, it is important to screen several nitrogen sources by culturing. Some microalgae strains are known to be more capable of using organic nitrogen sources [22, 23].

In this study, urea, yeast extract, tryptone and potassium nitrate were compared at a nitrogen concentration of $4.4 \mathrm{~g} / \mathrm{L}$. Yeast extract and tryptone are preferred by C. sorokiniana as can be seen according to the combined growth curves of parallel runs (Fig. 2A). This is confirmed by evaluating both detection time (the shorter the better), to achieve maximum changes in impedance and final cell number (Fig. 2B).

The impedance did not change significantly by using urea and $\mathrm{KNO}_{3}$ compared to the control reactor which did not contain any nitrogen sources. However, they both differ from the empty cells suggesting some algal activity, which can be explained by either endogenous nitrogen utilization or according to some reports [24, 25]. According to Sharma et al., urea supports the growth of Chlorella sp. under near autotrophic conditions [26], but in our experiments an increase in cell numbers was not remarkable. The maximum specific growth rate was doubled when yeast extract was used instead of tryptone (Fig. 1A).

\subsection{Comparison of carbon sources}

The growth of Chlorella sorokiniana on acetate has been tested by several studies under mixotrophic conditions. C. sorokiniana was successfully grown on BG-11 media supplemented with $1 \mathrm{~g} \mathrm{C} / \mathrm{L}$ acetate [27] and on synthetic wastewater supplemented with up to $1.4 \mathrm{~g} \mathrm{C} / \mathrm{L}$ acetate, but growth was completely inhibited at $4.2 \mathrm{~g} \mathrm{C} / \mathrm{L}$ [28]. The acetate is assimilated through the glyoxylate cycle and can be converted into Acetyl-CoA that produces organic compounds for the metabolic pathway gluconeogenesis. Acetate is also a key molecule in lipid anabolism [29]. Therefore, the availability of acetate under mildly heterotrophic or mixotrophic conditions significantly affects the final concentration and composition of biomass. 1 and $2 \mathrm{~g}$ $\mathrm{C} / \mathrm{L}$ were tested with a glucose origin and $1 \mathrm{~g} \mathrm{C} / \mathrm{L}$ with an acetate origin.

$1 \mathrm{~g} \mathrm{C} / \mathrm{L}$ acetate resulted in a relatively low degree of growth with regard to $C$. sorokiniana as seen in Figs. 3
A

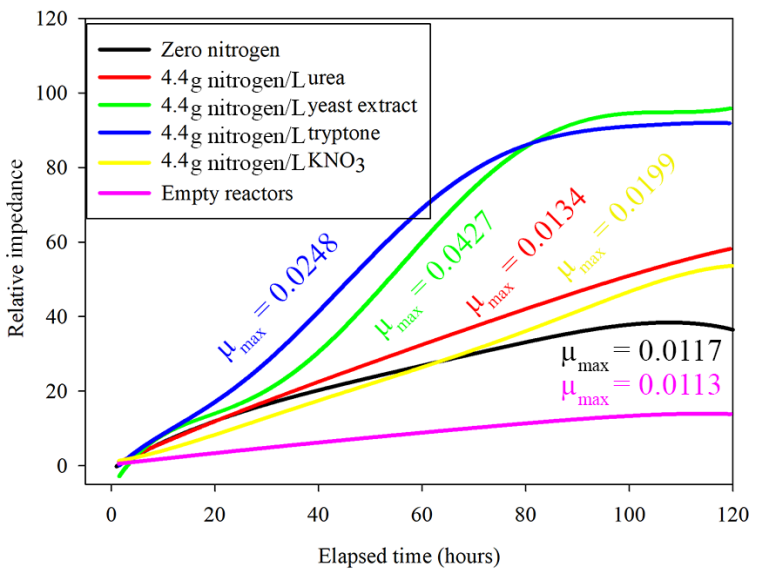

B

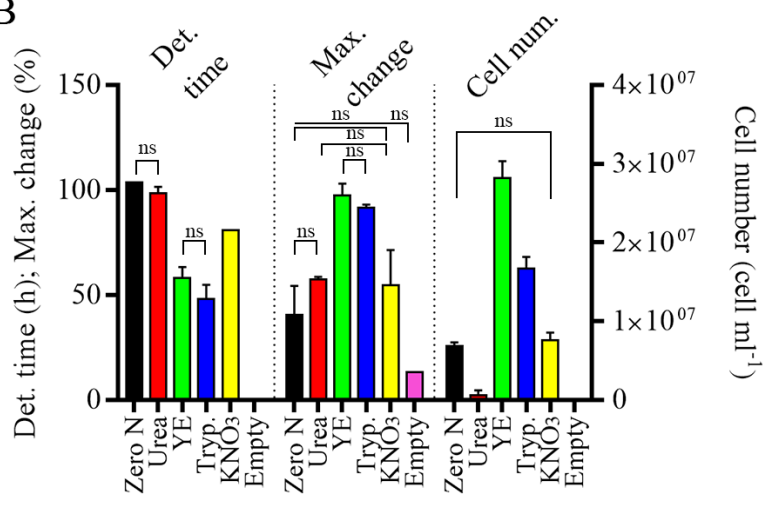

Fig. 2 Changes in relative impedance of a heterotrophic Chlorella sorokiniana culture with different nitrogen sources at $28^{\circ} \mathrm{C}$ in $\mathrm{HKU}$ media supplemented with $25 \mathrm{~g} / \mathrm{L}$ glucose. A) $5^{\text {th }}$ order regression line fitted onto the whole combined dataset per experimental setup. B) effect of the nitrogen source on the detection time, maximum changes in impedance and final cell number. Data were expressed as the means and standard deviations of three replicates. NS - statistically not significant differences.

and 4, even though the C:N:P molar ratio was sufficient (i.e. 14:2:1). The changes in impedance measured in the case of growth on acetate in the HKU medium did not differ from those controlled experiments where any carbon sources or algal cells were excluded. The preference for glucose was clear, but the difference between culturing on a glucose concentration of 1 and $2 \mathrm{~g} \mathrm{C} / \mathrm{L}$ was insignificant (Fig. 3).

These results directed our attention towards further investigations using the organic N-rich complex WIB media which can promote growth even in the absence of added carbon sources (Fig. 4). However, $1 \mathrm{~g} \mathrm{C} / \mathrm{L}$ equivalent glucose could further increase the degree of algal growth while carbon equivalent glycerol was significantly below the added-carbonless control. Acetate seemed to have a slightly positive effect in terms of the final cell 
A

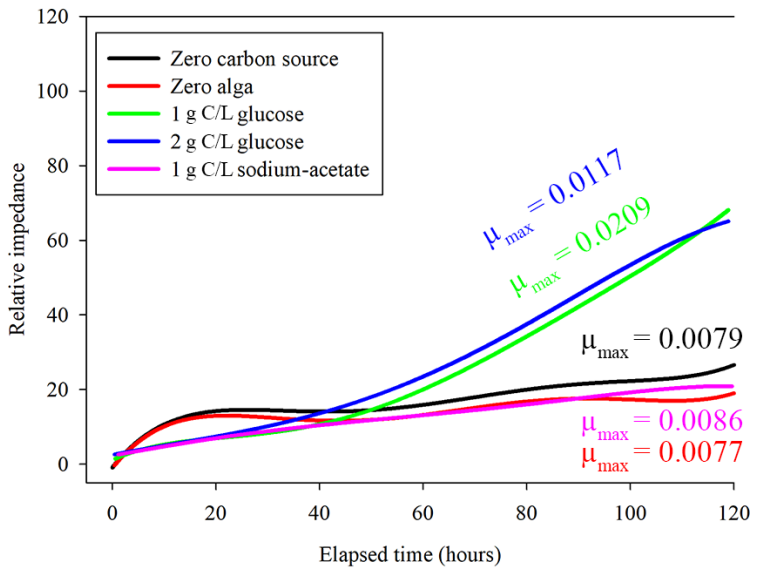

B

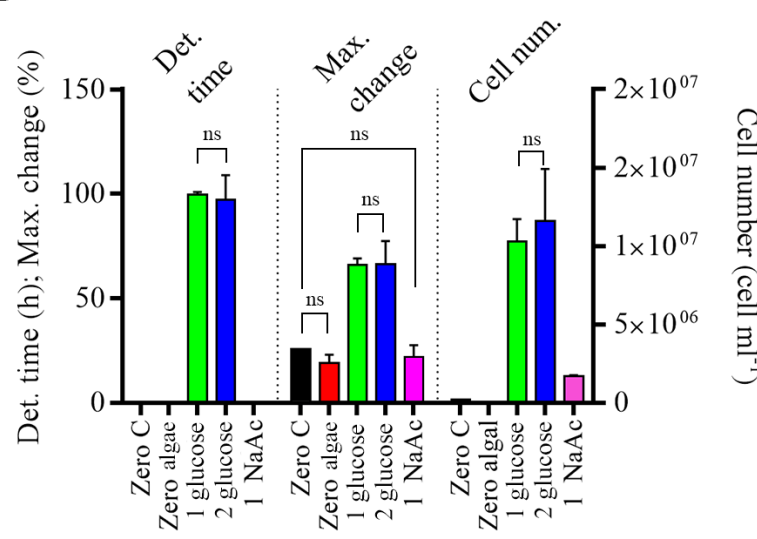

Fig. 3 Changes in relative impedance of the heterotrophic Chlorella sorokiniana culture with different carbon sources at $28^{\circ} \mathrm{C}$ in $\mathrm{HKU}$ media. A) $5^{\text {th }}$ order regression line fitted on the whole dataset per experimental setup. B) effect of a carbon source on the detection time, maximum changes in impedance and final cell number. Data are expressed as the means and standard deviations of three replicates. NS - statistically not significant differences.

number, but no effect could be detected on the detection time, maximum changes in impedance and specific growth rate in the WIB media. It was concluded that glycerol at a concentration of $1 \mathrm{~g} \mathrm{C} / \mathrm{L}$ caused a decrease in the impedance curve compared to the controlled experiment in the absence of carbon. This effect was distinct from other research where Chlorella was grown efficiently on 0.9-1.2 g C/L glycerol [30, 31]. It is assumed that Chlorella sorokiniana can grow on glycerol when mixotrophic conditions are applied and gas exchange provided.

Glucose enhanced the degree of growth effectively according to the detection time. The preference for glucose was determined by investigating the culturing conditions of C. sorokiniana in several publications [32, 33].

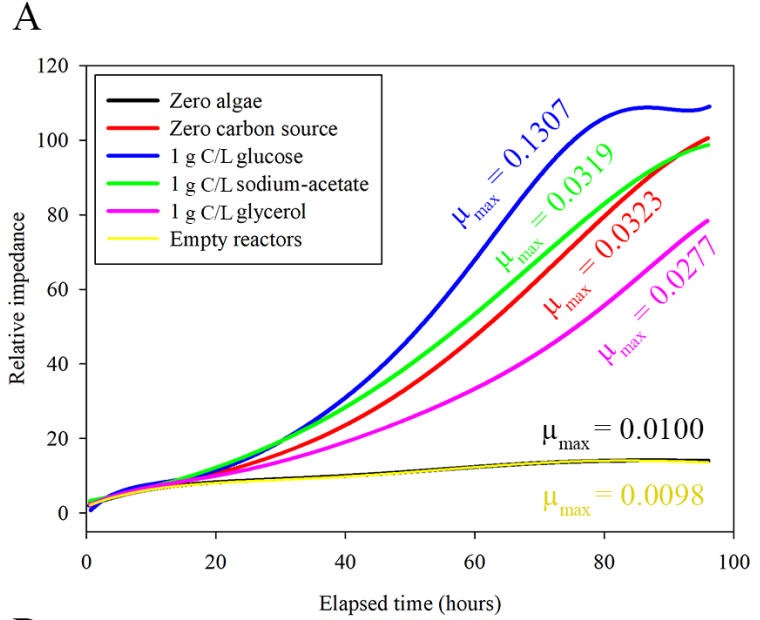

B

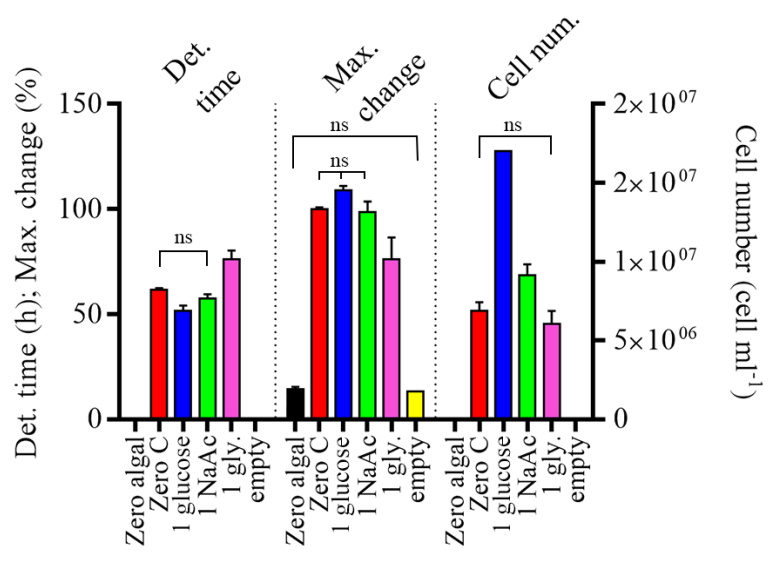

Fig. 4 Comparison of the changes in relative impedance of $C$. sorokiniana using different carbon sources at $28^{\circ} \mathrm{C}$ in WIB media. A) $5^{\text {th }}$ order regression line fitted on the whole dataset per experimental setup. B) effect of carbon sources on detection time, maximum changes in impedance and final cell number. Data were expressed as the means and standard deviations of three replicates. NS - statistically not significant differences.

\subsection{Estimating the glucose optimum}

Based on our results as described above, C. sorokiniana exhibited a preference for glucose under the circumstances provided by the microbioreactor BacTrac $4100^{\circledR}$, i.e. in the absence of stirring, illumination and gas exchange. The high cell density of growth in the presence of glucose has been described elsewhere [11, 34]. However, the effect of glucose concentration during indirect impedimetric measurements was of interest. Therefore, the effect on algal growth of increasing the glucose concentration from 0 to $40 \mathrm{~g} \mathrm{C} / \mathrm{L}$ was investigated at $28^{\circ} \mathrm{C}$.

An optimum glucose concentration was determined. As seen in Fig. 5B, the detection time was the shortest when the concentration was $8 \mathrm{~g} \mathrm{C} / \mathrm{L}$, whereas the maximum 
change in relative impedance as well as the final cell number were the greatest. Unfortunately, it is hard to explain the shape of the curve observed in the experiment where a glucose concentration of $32 \mathrm{~g} \mathrm{C} / \mathrm{L}$ was used because based on the final cell number it correlates strongly, but in terms of the detection time and maximum change in relative impedance it does not.

Further experiments are required to understand why a lower concentration of glucose was preferred. However, several stress factors were identified in microalgae cultivations [35], but to the best of our knowledge, osmotic stress caused by glucose or the mechanism of glucose inhibition has yet to be identified in microalgae.

Similar results were observed for other Chlorellas such as $C$. saccharophila which exhibited a optimum glucose concentration of almost $20 \mathrm{~g} / \mathrm{L}$ [36] and the growth of $C$. protothecoides which was also inhibited by a glucose concentration of $100 \mathrm{~g} / \mathrm{L}$ [37]. However, a relatively high glucose concentration was used in several studies of between 20 and $35 \mathrm{~g} / \mathrm{L}[38,39]$.

\section{Conclusion}

In this study an indirect impedance microbiological technique was used to screen various carbon and nitrogen sources for heterotrophic microalgae cultivation. Our results showed that the technique is applicable with media of different compositions but an added carbon source was required for signal detection.

The initial cell number determines the appearance of the impedance curves, therefore, it is necessary to test all experimental setups within the same run using various controls.

It was found that heterotrophically cultured Chlorella sorokiniana cannot utilize sodium acetate at a concentration of $3.41 \mathrm{~g} / \mathrm{L}$ (i.e. $1 \mathrm{~g} \mathrm{C} / \mathrm{L})$, and $3.56 \mathrm{~g} / \mathrm{L}(1 \mathrm{~g} \mathrm{C} / \mathrm{L})$ of glycerol resulted in the inhibition of growth. Glucose is one of the most preferable organic carbon sources for microalgae and its concentration has a strong influence on specific growth rates. Further studies are required to determine the effects of other combinations of substrates and environmental parameters on growth rates. The optimum concentration of glucose was found to be $20 \mathrm{~g} / \mathrm{L}(8 \mathrm{~g} \mathrm{C} / \mathrm{L})$.

A comparison of microalgae growth on different nutrient compositions using a BacTrac $4100^{\circledR}$ microbioreactor is limited to the provision of representative results, as the indirect measuring setup is not equipped with aeration and
A
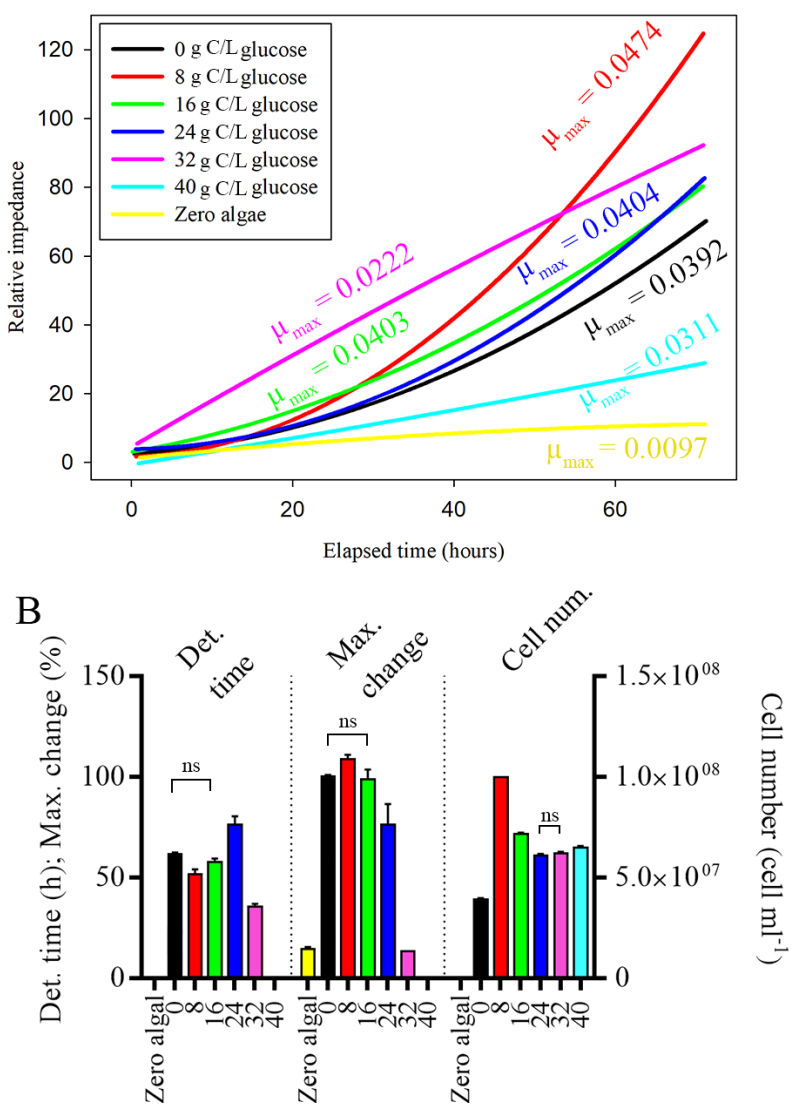

Fig. 5 Comparison of the changes in relative impedance of $C$. sorokiniana using different glucose concentrations at $28^{\circ} \mathrm{C}$ in WIB media. A) $5^{\text {th }}$ order regression line fitted on the whole dataset per experimental setup. B) the resultant parameters of the cultures with different glucose concentrations. Data were expressed as the means and standard deviations of three replicates. NS - statistically not significant differences.

stirring. However, the concentration of oxygen is often described as a limiting factor in heterotrophic microalgae fermentation [40-42]. Therefore, an investigation into the oxygen limit in these experiments is important.

According to our results, it can be concluded that impedance microbiology could help other heterotrophic microalgae fermentation institutions to implement the factorial design of experiments for the purpose of screening for nutrients and optimizing the composition of media.

\section{Acknowledgement}

The authors are grateful to AFo Biotech R\&D Ltd. (MÉL Biotech K+F Kft., Hungary) for the use of Digitizeit software and a BacTrac $4100^{\circledR}$ equipment. 


\section{References}

[1] Bravo-Fritz, C. P., Sáez-Navarrete, C. A., Herrera-Zeppelin, L. A., Varas-Concha, F. "Multi-scenario energy-economic evaluation for a biorefinery based on microalgae biomass with application of anaerobic digestion", Algal Research, 16, pp. 292-307, 2016. https://doi.org/10.1016/j.algal.2016.03.028

[2] Harun, R., Davidson, M., Doyle, M., Gopiraj, R., Danquah, M., Forde, G. "Technoeconomic analysis of an integrated microalgae photobioreactor, biodiesel and biogas production facility", Biomass and Bioenergy, 35(1), pp. 741-747, 2011.

https://doi.org/10.1016/j.biombioe.2010.10.007

[3] Costa, S. S., Miranda, A. L., Andrade, B. B., Assis, D. D. J., Souza, C. O., de Morais, M. G., Costa, J. A. V., Druzian, J. I. "Influence of nitrogen on growth, biomass composition, production, and properties of polyhydroxyalkanoates (PHAs) by microalgae", International Journal of Biological Macromolecules, 116, pp. 552-562, 2018. https://doi.org/10.1016/j.ijbiomac.2018.05.064

[4] Borowitzka, M. A. "High-value products from microalgaetheir development and commercialisation", Journal of Applied Phycology, 25(3), pp. 743-756, 2013.

https://doi.org/10.1007/s10811-013-9983-9

[5] Tsiplakou, E., Abdullah, M. A. M., Skliros, D., Chatzikonstantinou, M., Flemetakis, E., Labrou, N., Zervas, G. "The effect of dietary Chlorella vulgaris supplementation on micro-organism community, enzyme activities and fatty acid profile in the rumen liquid of goats", Journal of Animal Physiology and Animal Nutrition, 101(2), pp. 275-283, 2017.

https://doi.org/10.1111/jpn.12521

[6] Ayre, J. M., Moheimani, N. R., Borowitzka, M. A. "Growth of microalgae on undiluted anaerobic digestate of piggery effluent with high ammonium concentrations", Algal Research, 24, pp. 218-226, 2017.

https://oi.org/10.1016/j.algal.2017.03.023

[7] Lizzul, A. M., Hellier, P., Purton, S., Baganz, F., Ladommatos, N., Campos, L. "Combined remediation and lipid production using Chlorella sorokiniana grown on wastewater and exhaust gases", Bioresource Technology, 151, pp. 12-18, 2014.

https://doi.org/10.1016/j.biortech.2013.10.040

[8] Wang, T., Ge, H., Liu, T., Tian, X., Wang, Z., Guo, M., Chu, J., Zhuang, Y. "Salt stress induced lipid accumulation in heterotrophic culture cells of Chlorella protothecoides: Mechanisms based on the multi-level analysis of oxidative response, key enzyme activity and biochemical alteration", Journal of Biotechnology, 228, pp. 18-27, 2016.

https://doi.org/10.1016/j.jbiotec.2016.04.025

[9] Negi, S., Barry, A. N., Friedland, N., Sudasinghe, N., Subramanian, S., Pieris, S., Holguin, F. O., Dungan, B., Schaub, T., Sayre, R. "Impact of nitrogen limitation on biomass, photosynthesis, and lipid accumulation in Chlorella sorokiniana", Journal of Applied Phycology, 28(2), pp. 803-812. 2016.

https://doi.org/10.1007/s10811-015-0652-z
[10] Wang, T., Tian, X., Liu, T., Wang, Z., Guan, W., Guo, M., Chu, J., Zhuang, Y. "A two-stage fed-batch heterotrophic culture of Chlorella protothecoides that combined nitrogen depletion with hyperosmotic stress strategy enhanced lipid yield and productivity", Process Biochemistry, 60, pp. 74-83. 2017.

https://doi.org/10.1016/j.procbio.2017.05.027

[11] Huang, A., Sun, L., Wu, S., Liu, C., Zhao, P., Xie, X., Wang, G. "Utilization of glucose and acetate by Chlorella and the effect of multiple factors on cell composition", Journal of Applied Phycology, 29(1), pp. 23-33, 2017.

https://doi.org/10.1007/s10811-016-0920-6

[12] Xie, X., Huang, A., Gu, W., Zang, Z., Pan, G., Gao, S., He, L., Zhang, B., Niu, J., Lin, A., Wang, G. "Photorespiration participates in the assimilation of acetate in Chlorella sorokiniana under high light", New Phytologist, 209(3), pp. 987-998, 2016.

https://doi.org/10.1111/nph.13659

[13] Li, T., Zheng, Y., Yu, L., Chen, S. "Mixotrophic cultivation of a Chlorella sorokiniana strain for enhanced biomass and lipid production", Biomass and Bioenergy, 66, pp. 204-213, 2014. https://doi.org/10.1016/j.biombioe.2014.04.010

[14] Chen, B.-Y., Lee, C.-H., Chang, J.-S., Hsueh, C.-C. "Impedance fingerprint selection of DHA-producing photoautotrophic microalgae", Journal of the Taiwan Institute of Chemical Engineers, 57, pp. 36-41, 2015. https://doi.org/10.1016/j.jtice.2015.05.016

[15] Bancalari, E., Bernini, V., Bottari, B., Neviani, E., Gatti, M. "Application of Impedance Microbiology for Evaluating Potential Acidifying Performances of Starter Lactic Acid Bacteria to Employ in Milk Transformation", Frontiers in Microbiology, 7, pp. 1-11, 2016. https://doi.org/10.3389/fmicb.2016.01628

[16] Silley, P., Forsythe, S. "Impedance microbiology-a rapid change for microbiologists", Journal of Applied Biotechnology, 80(3), pp. 233-243, 1996. https://doi.org/10.1111/j.1365-2672.1996.tb03215.x

[17] Mortari, A., Adami, A., Lorenzelli, L. "An unconventional approach to impedance microbiology: Detection of culture media conductivity variations due to bacteriophage generated lyses of host bacteria", Biosensors and Bioelectronics, 67, pp. 615-620, 2015. https://doi.org/10.1016/j.bios.2014.09.075

[18] Ebina, Y., Ekida, M., Hashimoto, H. "Origin of changes in electrical impedance during the growth and fermentation process of yeast in batch culture", Biotechnology and Bioengineering, 33(10), pp. 1290-1295, 1989. https://doi.org/10.1002/bit.260331010

[19] Gong, X.-D., Chen, F. "Rapid detection of heterotrophic growth of Haematococcus pluvialis using indirect conductimetry", Biotechnology Techniques, 11(11), pp. 841-844, 1997. https://doi.org/10.1023/A:1018489611688

[20] Li, T., Zheng, Y., Yu, L., Chen, S. "High productivity cultivation of a heat-resistant microalga Chlorella sorokiniana for biofuel production", Bioresource Technology, 131, pp. 60-67, 2013. https://doi.org/10.1016/j.biortech.2012.11.121 
[21] Johnson, X., Alric, J. "Central Carbon Metabolism and Electron Transport in Chlamydomonas reinhardtii: Metabolic Constraints for Carbon Partitioning between Oil and Starch", Eukaryotic Cell, 12(6), pp. 776-793, 2013. https://oi.org/10.1128/EC.00318-12

[22] Azma, M., Mohamed, M. S., Mohamad, R., Rahim, R. A., Ariff, A. B. "Improvement of medium composition for heterotrophic cultivation of green microalgae, Tetraselmis suecica, using response surface methodology", Biochemical Engineering Journal, 53(2), pp. 187-195, 2011. https://doi.org/10.1016/j.bej.2010.10.010

[23] Kim, G., Mujtaba, G., Lee, K. "Effects of nitrogen sources on cell growth and biochemical composition of marine chlorophyte Tetraselmis sp. for lipid production", ALGAE, 31(3), pp. 257-266, 2016.

https://doi.org/10.4490/algae.2016.31.8.18

[24] Yang, L., Chen, J., Qin, S., Zeng, M., Jiang, Y., Hu, L., Xiao, P., Hao, W., Hu, Z., Lei, A., Wang, J. "Growth and lipid accumulation by different nutrients in the microalga Chlamydomonas reinhardtii", Biotechnology for Biofuels, 11(1), pp. 40, 2018. https://doi.org/10.1186/s13068-018-1041-z

[25] Chu, F.-F., Chu, P.-N., Cai, P.-J., Li, W.-W., Lam, P. K. S., Zeng, R. J. "Phosphorus plays an important role in enhancing biodiesel productivity of Chlorella vulgaris under nitrogen deficiency", Bioresource Technology, 134, pp. 341-346, 2013. https://doi.org/10.1016/j.biortech.2013.01.131

[26] Sharma, A. K., Sahoo, P. K., Singal, S., "Influence Of Different Nitrogen And Organic Carbon Sources On Microalgae Growth And Lipid Production", IOSR Journal of Pharmacy and Biological Sciences, 10(1), pp. 48-53, 2015. https://doi.org/10.9790/3008-10114853

[27] Turon, V., Baroukh, C., Trably, E., Latrille, E., Fouilland, E., Steyer, J.-P. "Use of fermentative metabolites for heterotrophic microalgae growth: Yields and kinetics", Bioresource Technology, 175, pp. 342-349, 2015.

https://doi.org/10.1016/j.biortech.2014.10.114

[28] Ogbonna, J. C., Yoshizawa, H., Tanaka, H. "Treatment of high strength organic wastewater by a mixed culture of photosynthetic microorganisms", Journal of Applied Phycology, 12(35), pp. 277284, 2000.

https://oi.org/10.1023/a:1008188311681

[29] Yang, W., Catalanotti, C., Wittkopp, T. M., Posewitz, M. C., Grossman, A. R. "Algae after dark: mechanisms to cope with anoxic/hypoxic conditions", The Plant Journal, 82(3), pp. 481-503, 2015.

https://doi.org/10.1111/tpj.12823

[30] O'Grady, J., Morgan, J. A. "Heterotrophic growth and lipid production of Chlorella protothecoides on glycerol", Bioprocess and Biosystems Engineering, 34(1), pp. 121-125, 2011. https://doi.org/10.1007/s00449-010-0474-y

[31] Paranjape, K., Leite, G. B., Hallenbeck, P. C. "Effect of nitrogen regime on microalgal lipid production during mixotrophic growth with glycerol", Bioresource Technology, 214, pp. 778-786, 2016. https://doi.org/10.1016/j.biortech.2016.05.020
[32] Qiao, H., Wang, G. "Effect of carbon source on growth and lipid accumulation in Chlorella sorokiniana GXNN01", Chinese Journal of Oceanology and Limnology, 27(4), pp. 762-768, 2009. https://doi.org/10.1007/s00343-009-9216-x

[33] Zheng, Y., Li, T., Yu, X., Bates, P. D., Dong, T., Chen, S. "Highdensity fed-batch culture of a thermotolerant microalga Chlorella sorokiniana for biofuel production", Applied Energy, 108, pp. 281287, 2013.

https://doi.org/10.1016/j.apenergy.2013.02.059

[34] Bumbak, F., Cook, S., Zachleder, V., Hauser, S., Kovar, K. "Best practices in heterotrophic high-cell-density microalgal processes: Achievements, potential and possible limitations", Applied Microbiology and Biotechnology, 91(1), pp. 31-46, 2011. https://doi.org/10.1007/s00253-011-3311-6

[35] Minhas, A. K., Hodgson, P., Barrow, C. J., Adholeya, A. "A Review on the Assessment of Stress Conditions for Simultaneous Production of Microalgal Lipids and Carotenoids", Frontiers in Microbiology, 7, pp. 546, 2016. https://doi.org/10.3389/fmicb.2016.00546

[36] Isleten-Hosoglu, M., Gultepe, I., Elibol, M. „Optimization of carbon and nitrogen sources for biomass and lipid production by Chlorella saccharophila under heterotrophic conditions and development of Nile red fluorescence based method for quantification of its neutral lipid content", Biochemical Engineering Journal, 61, pp. 11-19, 2012.

https://doi.org/10.1016/j.bej.2011.12.001

[37] Shi, X.-M., Liu, H.-J., Zhang, X.-W., Chen, F. "Production of biomass and lutein by Chlorella protothecoides at various glucose concentrations in heterotrophic cultures", Process Biochemistry, 34(4), pp. 341-347, 1999.

https://doi.org/10.1016/S0032-9592(98)00101-0

[38] Wu, Z., Shi, X. "Optimization for high-density cultivation of heterotrophic Chlorella based on a hybrid neural network model", Letters in Applied Microbiology, 44(1), pp. 13-18, 2007. https://doi.org/10.1111/j.1472-765X.2006.02038.x

[39] Sun, N., Wang, Y., Li, Y.-T., Huang, J.-C., Chen, F. "Sugar-based growth, astaxanthin accumulation and carotenogenic transcription of heterotrophic Chlorella zofingiensis (Chlorophyta)", Process Biochemistry, 43(11), pp. 1288-1292, 2008. https://doi.org/10.1016/j.procbio.2008.07.014

[40] de Swaaf, M. E., Pronk, J. T., Sijtsma, L. „Fed-batch cultivation of the docosahexaenoic-acid-producing marine alga Crypthecodinium cohnii on ethanol", Applied Microbiology and Biotechnology, 61(1), pp. 40-43, 2003. https://doi.org/10.1007/s00253-002-1118-1

[41] Gerken, H., Liu, J., Sun, Z. "Recent Advances in Microalgal Biotechnology", OMICS International, 2014. https://doi.org/10.4172/978-1-63278-066-9-67

[42] Smith, R. T., Bangert, K., Wilkinson, S. J., Gilmour, D. J. "Synergistic carbon metabolism in a fast growing mixotrophic freshwater microalgal species Micractinium inermum", Biomass and Bioenergy, 82, pp. 73-86, 2015. https://doi.org/10.1016/j.biombioe.2015.04.023 